Textures and Microstructures, 1982, Vol. 4, p. 243

0730-3300/82/0404-0243 \$06.50/0

(C) Gordon and Breach Science Publishers Inc., 1982

Printed in Great Britain

\title{
Papers to Appear in Volume 5 Number 1
}

D. Gapais and S. H. White, Ductile shear bands in a naturally deformed quartzite

C. J. L. Wilson, Texture and grain growth during the annealing of ice

S. H. White, D. Evans and D.-L. Zhong, Fault rocks of the Moine Thrust Zone: Microstructures and textures of selected mylonites

R. Mark Bailey and H. R. Wenk, Observations of microcrystalline plagioclase spherulites with the transmission electron microscope 